\title{
Wyrd Poetics: Collapsing Timescapes and Untimely Desires in The Ruin
}

\author{
Lisa M. C. Weston
}

check for

updates

Citation: Weston, Lisa M. C. 2022. Wyrd Poetics: Collapsing Timescapes and Untimely Desires in The Ruin. Humanities 11: 35. https://doi.org/ 10.3390/h11020035

Received: 15 December 2021 Accepted: 24 February 2022 Published: 1 March 2022

Publisher's Note: MDPI stays neutral with regard to jurisdictional claims in published maps and institutional affiliations.

Copyright: (C) 2022 by the author. Licensee MDPI, Basel, Switzerland. This article is an open access article distributed under the terms and conditions of the Creative Commons Attribution (CC BY) license (https:// creativecommons.org/licenses/by/ $4.0 /)$.
Department of English, California State University, Fresno, CA 93740, USA; lisaw@csufresno.edu

\begin{abstract}
John Niles suggests that Old English poems often "demand [...] attention not only to the possible nuances of meaning of every word, but also to the spaces where no words are written and no story told". Such spaces, he argues, invite readers into a kind of intellectual "play" that constitutes, in fact, participation, even collaboration, in the creation of meaning. However, what of more literal spaces in texts, not perceptual gaps composed by a poet, but rather material gaps "crafted" by manuscript damage? What more radical, "veered" reading follows if we pay attention to the physical damage, neither to lament the loss nor to restore what might have been there once, but rather to collaborate with its void? The damage to the final folios of the Exeter Book manuscript means that we read a different poem from any "intact" or "original" text we may try to (re)create; we read something that not only responds to, but also reifies the material effects of time and wyrd, the powerful other-than-human force that plays so prominent a role in the poem. This essay seeks to unsettle the text by engaging with both the poem's extant words and the silent spaces of wyrd's traces "inscribed" upon the material manuscript.
\end{abstract}

Keywords: The Ruin; Old English poetics; Exeter Book

John Niles suggests that Old English poems often "demand [...] attention not only to the possible nuances of meaning of every word, but also to the spaces where no words are written and no story told (Niles 2006, p. 4)". Such spaces, he argues, invite readers into a kind of intellectual "play" that constitutes, in fact, participation, even collaboration, in the creation of meaning. However, what of more literal spaces in texts: not perceptual gaps composed by a poet, but rather material gaps "crafted" by manuscript damage? What more radical, "veered" reading (Royle 2011) follows if we pay attention to the physical damage as well as the words that persist, and do so neither to lament the loss nor to restore what might have been there once, but rather to collaborate with its void?

The ruined state of The Ruin has attracted many modern readers, translators, and critics of Old English poetry. ${ }^{1}$ Even the poem's title-in itself a modern interpretive act that speaks to its reception in the present, as much as its composition in the early medieval past - might seem to foreground its material state. The damage to the final folios of the Exeter Book manuscript means that we read a different poem from any "intact" or "original" text we may try to (re)create: we read something that not only responds to, but also reifies the material effects of time and wyrd, the powerful other-than-human force that plays so prominent a role in the poem. In effect, our reading requires us to engage and collaborate with both the poet's extant words and wyrd's silent spaces.

Emily Thornbury has argued for the influence of the late eighteenth- and early nineteenthcentury vogue for the picturesque on foundational later nineteenth- and twentieth-century editing practices, especially in regard to the treatment of damaged texts, such as The Ruin. ${ }^{2}$ The Romantic love of ruins in the landscape-the Gothic $(\mathrm{k})$ landscape, if you will —has not only led editors to leave an imperfect text un-emended, but may also induce readers to fetishize them, to make ruined texts emblematic of the historical period and its literature-and consequently, perhaps, to canonize the elegiac as the characteristic mode of Old English 
literature (Trilling 2009). Unlike "ruins" that could be and were purpose-built into the picturesque landscape, however, neither the Old English poet who composed the poem nor the scribe who incorporated it into the Exeter Book could know, let alone design, the poem's ruin. Nevertheless, in a queer untimely irony, the poem accommodates that possibility-that probability, even perhaps inevitability-in a way that speaks particularly to those of us who read the ruined text through our own twenty-first century engagements with cultural and environmental collapse, within our own anthropocene landscape of disaster and destruction.

Our world, as Eugene Thacker notes in his In the Dust of this Planet, "is increasingly unthinkable". Similar to that depicted in the poem, our world knows the realities and consequences of war and famine - and of plague: we read the poem's references to pestilence in the context of our own current COVID-19 pandemic and the possibility of other diseases yet to emerge from viral hot zones. ${ }^{3}$ Given the multitude of potential, even probable "apocalyptic" events, including violent storms that testify to the reality of environmental collapse, we struggle to confront the realities of a perilous contingency. Such challenges to human agency and pride, Thacker suggests, make the literary genre and mode of cosmic horror especially attractive to contemporary philosophers as something to think with, not least because of its focus on encounters that disrupt our ability to feel at home in the world and undermine complacent anthropocentrism by revealing the universe not as hostile (for even that would place humans at the center of things) so much as radically alien in its indifference. ${ }^{4}$ Additionally, in its untimeliness, it invokes an unknowable and otherthan-human deep time embracing both geological and primal past and apocalyptic future (Noys 2008). Such encounters elicit fear, certainly, and horror, but also often a fascination and perverse attraction, a paradoxical pleasure and even desire. It is precisely that mingled horror and desire that this essay addresses, as it offers a reading that seeks to unsettle the text by engaging with existential dread, yet finding pleasure in that engagement. Mixing horror and desire in its collaboration with (rather than opposition to, or denial or lament of) temporal decay, such a reading may prompt us to imagine new relationships with/in our own "endscape", as Sara Pritchard calls a landscape that is experienced as always already lost (Pritchard 2019).

Wrætlic is pes wealstan, wyrde gebræcon, the poem begins, burgstede burston, brosnad enta geweorc. "wondrous is this wall-stone, broken by fate, the fortress shattered, the work of giants decays". The deictic pes in the first line invokes a materiality and a physical presence for that stone (and for the wall of which that stone is imagined to be a part, and for the larger structure of whatever building that wall may be a part) that paradoxically foregrounds its literal absence: there is, after all, no stone before our eyes, only the words on folios $123 \mathrm{v}$ and 124r of the Exeter Book manuscript, or more likely a modern printed (and critically annotated) edition of the poem. The poem thereby entangles at least two poetic encounters: the one between the poem's speaker and the broken stone, and the other between ourselves and the words on the page and/or as a sequence of sounds when we recite the poem aloud. The literal presence of the poem, that is, replaces and obscures the absence of the stone.

The elision of the stone and the text conflates the past that the stone reifies with the present and futures in which the poem is, and will perhaps (but not necessarily inevitably) continue to be read. As Janet Bately notes, the poem plays with the underlying binary tense system of Old English and its distinction of (manifest) the past from ongoing (manifesting, but not yet completely manifest) present-future. For Bately, The Ruin's structure "hinges on the opposition" between the two, while simultaneously "emphasiz[ing] the intimate links between the two (Bately 1984, p. 9)". In its first two lines, for example, the present tense (is in line 1a and brosnað in line 2b) encloses the resolved perfect (gebræcon in $1 \mathrm{~b}$ and burston in line 2a), an enclosure further substantiated by the interweaving of the alliteration on $w$ (wrætlic and wealstan, line 1a; wyrde, line $1 \mathrm{~b}$; geweorc, line $2 \mathrm{~b}$ ) and $b$ (gebræcon, line $1 \mathrm{~b}$; burgstede and burston, line 2a; brosnad, line $2 \mathrm{~b}$ ). For Rory Crittenn, similarly, "the manipulation of the Old English tense system in the text's opening section establishes a mobile timeframe" that situates us "at an indeterminate point of intersection between the past, the present, and the future of the speaker (Critten 2019, p. 210)". The quasi-gnomic 
use of the present in the second line's brosnað enta geweorc (line 2b), "the work of giants crumbles", invokes an eternal present that transcends the particular moment of the initial wrætlic is pes wealstan (line 1a), while reflecting the (past) manifestations of the eternally recurrent in the enclosed half-lines.

The collapse of the temporal difference in these first lines also manifests itself in the text's creation of a speaker unanchored in a single moment. Unlike the other so-called elegies-especially The Wanderer, The Seafarer, and The Wife's Lament-alongside which it is most often read, The Ruin lacks a first-person speaker: there is no one, singular "I" and consequently no one "now" in which to fix the poem's present. Who, in fact, is speaking, and when? The disembodied and temporally unfixed voice of the poem's ostensible speaker incorporates-embodies and is embodied in-a recursive series of observers across time, in a recurrent series of temporal moments, in which wyrd is made manifest in the absent yet present brokenness of the stone and (for us) the poem: those of its early medieval composition and initial reception, of its consequent commitment to the late-tenth-century manuscript, and of multiple readings of that manuscript down to our own in the twenty-first century. As The Ruin stages these encounter(s) with wyrd in the wrætlic wallstone (and/or the poem as materially extant in the manuscript), it facilitates an emergent subjectivity, which elides speaker and audience, poet and reader, even as it both collaborates with wyrd in an intra-action from which subjects and objects emerge in times(s) and space(s), but remain contingent as they are constantly renegotiated and redefined. ${ }^{5}$

In The Wanderer, by contrast, a defined " $\mathrm{I}$ " speaking from (and anchored in) a definable "now" exhorts us, ongietan sceal gleaw hæle hu gæstlic bið/Ponne ealle pisse worulde wela weste stonded, "the wise man must recognize how ghastly it will be when all this world's wealth stands waste" (lines 73-74) in an apocalyptic future. That future is, to be sure, already present in the ruins of the past:

swa nu missenlic geond pisne middangeard

winde biwaune weallas stondap,

hrime bihrorene, hryðge pa ederas. (lines 75-77)

(So now in various places throughout this middle-earth walls stand blown by wind, covered with frost, the buildings snow-swept.)

Time overlaps as the desolation continues in the present-as woriað pa winsalo. Walend licgað/dreame bedrorene, "the wine halls topple. The rulers lie deprived of joy", because (in the past) dugup eal gecrong/wlonc bi wealle, "the troop is all perished, proud by the wall" (pp. 78-80a). An envisioned future, physically present, depends upon an image of the past shared by the speaker and the reader in the "now" of the text, where

stondeð nu on laste leofre dugupe

weal wundrum heah, wyrmlicum fah.

Eorlas fornoman asca prype,

wæpen wælgifru, wyrd seo mære,

ond pas stanhleopu stormas cnyssað,

hrið hreosende hrusan bindeð

wintres woma, ponne won cymeð,

nipeð nihtscua, norpan onsendeð

hreo hæglfare hælepum on andan. (lines 97-105)

(Stands now in the track of the dear troop a wall wondrously high, adorned with serpentine patterns. The might of ash-spears took away the men, weapons eager for slaughter, powerful wyrd, and storms beat the cliffs, fierce blizzards bind the earth, winter's chaos, as darkness comes, night-shadows draw near, and from the north come fierce hail-storms maliciously against men.)

The speaker offers for our consideration a future when the earth will be a barren, stormbeaten wasteland-something we can (fore)see in our shared present as we gaze with the speaker upon the ruins of the past. Such consideration, The Wanderer suggests, should 
move us to a kind of penitential horror: a contemplation of wyrd and its effects should prepare us for the dissolving of time and temporal difference into eternity, should inspire us to willingly trade the transient attractions of this world for those of next. In the working of a wyrd hostile to human aspiration and agency and in the context of eternity time collapses, what is past is present, is inevitable future. Yet, the three tenses and temporalities remain distinguishable because of the speaker's location in time.

However, is this the only possible response to the apocalypse, at least in a text like The Ruin in which the speaker (and consequently audience) is less defined and temporally fixed, and in which wyrd is less antagonistic than indifferent to humanity? ${ }^{6}$ For if wyrd is revealed and experienced horrifically in quasi-apocalyptic destruction and decay, in The Ruin, that same brokenness is also fascinating: it is wrætlic, "wondrous", and may elicit not only horror, but also pleasure and desire. Wraetlic is, in fact, the first word of The Ruin, alliteratively bound and collocated with both wealstan and wyrd: the wall-stone is (present tense) wraetlic, not despite but specifically because it has been broken by wyrd. Broken by wyrd, the wealstan (and the poem that describes it, equally "broken" as we read it) is wrætlic by and through that breaking-and wrætlic-ness is something that exceeds and therefore troubles ordinary temporal logic.

The word wrætlic, as Peter Ramey notes, is uniquely Old English, unattested in later Middle English texts and thus redolent for us of an untimely obsolescence. It has "no precise counterpart" in other Germanic languages, nor is it used to gloss any Latin aesthetic term, including the mirabile we might expect from its connection with wonder (Ramey 2017, p. 460). Extant only in poetic texts, it derives from-is essentially a simile based on-the even more rarely attested noun wrætt, "jewel" or "ornament", and especially insofar as both are cognate with writan, intrinsically connected to the materiality of an engraved object, the physical presence of a written text. However, in the usage of the word, as Ramey argues, the physical presence implied by that materiality is also deeply implicated with the effect that presence has on the one who handles or otherwise engages with it, and with the skills of its maker as well. To describe something as wrætlic is therefore to produce an essential core estrangement, a disorientation and a consequent re-negotiation of the agencies of object, maker and handler. To begin The Ruin with the word effectively requires a reader to participate in the act of creating the text as read, of seeing and perceiving both text and world wrætlic-ly. For Ramey, this means the focus shifts from the "ravages of time" on the wall-stone and the depredations of wyrd to its "cunning construction" and (as in a riddle) our perception (Ramey 2017, p. 469).

Certainly wrætlic-ness has something to do with style and skill, whether in the binding of stone into walls or of words into poems. This seems, in fact, something of a formulaic collocation. Maxims II refers to the wrætlic weallstana geweorc and the Gifts of Men to those who know how to plan the wrætlice weorc of building a high-timbered hall (line 44). Additionally, in Exodus, the "wondrous highway", wrætlicu wægfaru, through the Red Sea is also metaphorically a house with watery foreweallas and heavenly hrof (line 297). In Riddle 39, the contested solution-which may be time, day, moon, or speech, woh wyrda gesceapu, "the twisted shape of wyrd and/or words", perhaps a pun-is an appropriately wrætlic ping to gesecganne (line 22). In Riddle 47, the book-moth riddle, that a worm should swallow men's songs is a wrætlicu wyrd and a wundor. Wrætlic-ness is thus intrinsically enigmatic play.

Wyrd can be interpreted within a specifically Christian context - in the context of, say, the Alfredian translation of Boethius' Consolation of Philosophy. Then again, especially as it appears in Old English poetry, it can seem a verbal fossil of sorts, a traditional, possibly preChristian concept surviving (like the poem's ruins) into poetic reuse. In Beowulf's famous proverb, wyrd oft nereð/unfægne eorl, ponne his ellen deah (lines 572b-573), wyrd- "fate" is the usual translation- "often saves an un-doomed warrior, if his courage holds". However, is the warrior "un-doomed" because his courage holds and wyrd responds to that courage? Or is he "undoomed" because he is always already saved by wyrd? If a courageous warrior was doomed, would or could wyrd help him anyway? What if an un-doomed warrior's courage failed? Or is to consider wyrd to confront the overlapping of two types of time, 
the human/secular within which causality is linear and the eternal/divine within which the past coincides with the present and future, rendering the distinction of cause and effect meaningless?

In The Ruin, wyrd is seo swipe (line 21), the "strong" or "powerful", and the same adjective characterizes wyrd in Solomon and Saturn (wyrd seo swiðe, line 444), Maxims II (wyrd bið swiðost, line 4), and The Seafarer (wyrd bið swipre, line 115). The Wanderer calls wyrd seo mære (line 99), as does The Menologium (mære wyrd, line 48), Elene (mæran wyrd, line 1062), and Genesis (mæro wyrd, line 1397). Whether mære should be read as "famous" or "infamous", "glorious" or "notorious", seems to vary: something along the lines of "manifest", something that becomes known, for good or ill might serve as a more inclusive translation. In The Wanderer, the landscape of wyrd seo mare (line 100b) embodies the tragic aftermath of heroic action and the antagonism of wæpen wælgifru (line 100a), "weapons greedy for slaughter". Additionally, again, eall is earfodlic eorpan rice, "all is hardship in this earthly realm," not least because onwended wyrda gesceaft weoruld under heofonum, (lines 106-7), "the shaping of wyrd changes the world under the heavens". In Genesis, wyrd is similarly wælgrimme, "slaughter-grim" (line 995). In Andreas, it is heard ond hetegrim (line 156), "harsh and hate-grim", and in The Dream of the Rood it is egeslic (line 74), "terrifying". In other uses, however, it is wyrd's enigmatic quality that is foregrounded. In Elene, wyrd is also dygle, "secret" or "obscure" (line 536), even as in Juliana it is ne ful cupe, "not fully known" (line 32): ineffable, observed not directly but rather through its effect on the material. Just as in The Ruin, the effects of wyrd confound even as they exemplify history and temporality; they can also elicit an appreciation of and a fascination with those effects.

Similar to The Wanderer, The Ruin's endscape, wrætlic and broken by wyrd, is one of winter and apocalypse:

Hrofas sind gehrorene, hreorge torras,

hrimgeat berofen, hrim on lime,

scearde scurbeorge, scorene, gedrorene,

ældo undereotene. (lines 3-6a)

(Roofs have collapsed, towers in ruins, frost-gate is broken, hoar-frost on the mortar, cut down, declined, undermined by age.)

It is an equally storm-battered world, and indeed The Ruin and The Wanderer employ much of the same vocabulary: The Wanderer's hrime bihrorene (line 77a) echoes, for example, in The Ruin's gehrorene (line 3a), hrimgeat (line 4a), and hrim (line 4b). This endscape invokes a cataclysmic, apocalyptic frozen future that may echo early medieval cultural memories of the late antique little ice age and other environmental phenomena of the so-called, but at times literal, "dark ages" of the poem's world. ${ }^{7}$ It conjures a world of entropy and disaster that we can read (sometimes paradoxically, ironically) alongside our contemporary awareness of and anxiety about the present existential threat of climate collapse and its future consequences: decreases in arctic ice and thawing permafrost, increasing temperatures, and changing weather patterns that bring more violent and frequent storms, rising sea levels, the destruction of ecosystems, and mass extinctions.

The poem addresses not one particular ruined site per se, so much as it does overlapping multiple manifestations of wyrd in the material world. The Ruin's world is a place of graves:

\section{Eorðgrap hafað}

Waldendwyrhtan forweorone, gelorene, heardgripe hrusan, op hund cnea werpeoda gewitan. (lines 6b-9a)

(The earth's grip holds the powerful makers, decayed, passed away, the hard grasp of the earth, until a hundred generations of the nations of men have passed away.)

The stone has remained, remains, will remain, ræghar ond readfah, "grey with lichen and redhued" and beset by storms (stormum) as time and history pass, rice æfter oprum, "one kingdom 
after another", op hund cnea gewitan (lines 6b-7a, 8b-9a), "until" — or while-“"a hundred generations of the nations of men pass away", either in the ongoing present-future or in the manifested past. Marking the passage of time by generations invokes notions of kinship, of dynastic succession. However, is that succession strictly and narrowly biological? Or, is it as much an imagined lineage, a fictive continuity, which provokes a nostalgia as much ideologically productive and prospective as retrospective, memorial, and elegiac? (Howe 1989; Trilling 2009) Additionally, if the notion of generations in any way promises reproductive futurity or constructs teleological history, it is teleological without a telos: cyclical and recursive rather than linear and genealogical. ${ }^{8}$

At the same time, memorializing temporal rupture, the imagined ruins of the poem constitute spatial markers of temporal difference and distance, even as each uncanny-horrifying and yet fascinating - cataclysm in the past elides with others past and present-future. The poem's described ruins are, at first glance, Roman, most likely those of somewhere like Bathalthough perhaps as read through the valences of the Biblical and allegorical Babylon. The final complete lines of the poem, for example (lines 38-43 or so), refer specifically to bapu. Elsewhere, the poem uses loan words torras, "towers" (line 3) and tigelum, "tiles" (line 30), and references to a "red arch" (teaforgeapan, line 30) would seem to imply Roman brickwork. Yet, to invoke an utterly deserted city is to ignore-to erase-the way real, non-poetic life continued in such places. In early medieval England Roman centers like London, Bath, Chester, and York were not completely abandoned, even if the focus of settlement had shifted from urban to suburban, from villa to estate to monastery, with old buildings used as quarries for re-usable stone and brick. The incorporation of Roman spolia was by no means uncommon, and early medieval recyclers probably knew quite well with whom and what such materials were associated: the patterns of re-use and appropriation of spaces, materials and architectural forms suggest, in fact, their deployment in a conscious re-formation of ideology, (re)establishment and authentication of authority, dynasty, and history (Eaton 2000; Ferhatovic 2019).

As broken by wyrd, moreover, the burgstede of the imagined city have crumbled, brosnað enta geweorc (line 2), "the old work of giants has decayed". Additionally, the giants point toward a pre-Roman antiquity. ${ }^{9}$ Putatively, Roman cities are recognizable as burgum (lines $2,21,25,37$ and 49), although (according to line 32a) they are gebrocen to beorgum, "broken into mounds" evocative of earlier Neolithic or bronze-age remains in the landscape. That ambiguity, that almost-pun, along with the essential difference, the non-human-ness of giants, suggests an even more primal past: something out of Germanic legend, perhaps, or something Biblically antediluvian, associated (such as Grendel) with the children of Cain and their construction of cities, the Canaanite giants of Numbers 13:33, or the Nephilim, the offspring of "the sons of God" (angels) with "the daughters of men" in Genesis 6:4.

Elsewhere, in Old English poetry, too, phrases, such as enta geweorc, blur the relatively recent Roman past and the more ancient and distant. In Andreas, the martyr is dragged to prison through mountains and along a (perhaps Roman?) stone highway that is nevertheless described as enta ærgeweorc (line 1232). The great stone pillars and columns he sees in that prison are equally the eald enta geweorc (line 1492), albeit storme bedrifine, "beaten by storms", as if they were landscape elements of deeper temporality. In The Wanderer, ypde swa pisne eardgeard ælda scyppend/oppæt burgwara breahtma lease/eald enta geweorc idlu stodon (line 85), "the Creator of men laid waste this earth until, bereft of city-dwellers' revelry, the old work of giants stood idle", as empty as that depicted in The Ruin. The sword hilt from Grendel's mere-with its depiction of Flood-is likewise enta ærgeweorc (Beowulf, 1677), as is the dragon's hlæwe, barrow-home and its treasures, enta geweorc and eald enta geweorc (lines 2715, 2773). Additionally, in a passage that echoes The Ruin's collocation of wrætlic-ness, walls, and wyrd, Maxims II tells us that ceastra beoð feorran gesyne, ordanc enta geweorc,/pa pe on pysse eorðan syndon,/wrætlic weallstana geweorc (lines 1-3a), "cities are seen from afar, the ingenious work of giants, which are on this earth, the ornate work of wall-stones". However, if The Ruin invokes the distant past, the age of giants before the flood as well as the more recent Roman occupation, the city's abandonment and the absence of human beings imply not only past battles and plagues, but also the on-going 
present/future obliteration of human artifice and ambition. The landscape of wyrd, that is, is pre-eminently a queer, untimely landscape of overlapping time, simultaneously both primal and apocalyptic, past and present/future.

There is, ultimately, a desire to be felt as an alien, and immaterial wyrd is made manifest and material. There is pleasure to be taken in the wraetlic, beautiful horror of this untimeliness, and the wrætlic-ness of the imagined wall impels the poem toward its own excessive, obsessive stylistic wrætlic-ness in the face of wyrd. The Ruin is remarkable for the elaboration of its verse. Formulaic collocations of words, repetitions of sounds, internal rhyme- one is tempted to think of such things as analogous to repetitions of history-bind the verse just as separate stones are bound together with wires. As early medieval builders strategically re-used roman stone, brick and tile, the poet re-uses poetic formulas, devices and motifs from both Old English and Anglo-Latin "word-hordes"-literary spolia-to form (and re-form) a depiction of a noble, wondrous but ultimately fragile and transitory world. As Christopher Abram notes, "The Ruin is itself a construction, an edifice of literary building-blocks which have been quarried from the works of past authors" in both Latin and Old English traditions (Abram 2000, p. 24). ${ }^{10}$ What results is something along the lines of an Old English reflex of a contemporary Anglo-Latin hermeneutic style that, through its excessive, even obsessive wrætlic-ness, defamiliarizes the banality of time and offers it for wonder and reflection-or perhaps something not unlike the thaumaturgic repetitions and sound play of the Old English metrical charms. Through defamiliarization, the poetic encounter-or rather encounters (plural) of the poet/speaker with the ruin resulting in the poem and those of readers with that poem, whether in its complete or ruined state-functions as what Nick Land calls "hyperstitions", moments and acts of backward precognition that allow the future to change the past as it is perceived in the present. ${ }^{11}$ That stylistic excess, that wraetlic-ness, is associated for us at least with the material existence of the poem in the Exeter Book-and with its own ruined state, its own capitulation to, or rather collaboration with, wyrd. Especially insofar as wrætlic is cognate with writan, the text's inscription manifests the emergent subjectivity of the untimely speaker of the poem's first eleven lines. Driven by the sound play on the page, perhaps we (similar to the performer of a charm) may speak the lines aloud, tasting them, feeling them, taking them into our bodies, and thereby manifesting our own encounter with speaker, text, and wyrd.

However, it is not only the extant words, but also their absence, which reify this encounter. Manuscript damage creates a very material caesura in line 12. A few scattered words and phrases survive-fel on (line 13a), grimme gegrunden (line 14a), orponc and ærsceaft (line 16), lamrindum beag (line 17b) —as the poem's elaborate wordplay shatters into a silence punctuated by inarticulate and uninterpretable syllables and individual letters. We can, and frequently do, attempt to repair the damage. We can read the shards as ironically appropriate and meaningful, or as Romantically elegiac and picturesque, or as conducive to some penitential moral. Or, we can attend more closely to what wyrd has destroyed and what it has preserved. In the poem's most common edited form, we can still hear the sounds of words persisting even as they are choked into silence. Images of the page-or better yet, a more direct, unmediated engagement with the Exeter Book as an artifact-may provoke us to experience across time, imaginatively, the moment of the wound, the sharp shock as the burning brand pierces the body of the codex, the searing heat, and the acrid smell of the singed manuscript's flesh.

As The Ruin continues after this first gap of past manuscript damage, present human imagination-both ours and the poet's-reanimates the bodies fallen by the walls and (re)populates the ice-bound ruins, through poetic wrætlic-ness, with inhabitants figured anachronistically, or better yet, trans-chronistically, as early medieval warriors who face the end of their civilization, their history, again and again, with every re-reading. From the stonework, the poet conjures a vision of prior waldend wyrhtan "powerful makers" (line 7) — either the original builders (if builders are ever original) or consequent rebuilders 
in the past-particularly noted for their skill in building a place that fosters as well as contains transient human joy:

hwætred in hringas, hygehrof gebond,

weall walanwirum wundrum togædere.

Beorht wæron burgræced, burnsele monige,

heah horngestreon. Heresweg micel,

meodoheall monig mondreama full,

oppæt pæt onwende wyrde seo swipe. (lines 19-24)

(Ingenious in rings the high roof was bound, the walls wondrously linked together with wires. Bright were the city's buildings, many halls, high gables. There was great sound of joy, many mead-halls full of revelry until wyrd the powerful changed that.)

Wyrd brings death in battle and from disease. Yet, although the builders skillful enough to repair the walls may have been few, and the stone work left to crumble, the present poet can nevertheless envision a world

Pær iu beorn monig

glædmod ond goldbeorht gleoma gefrætwed,

wlonc ond wingal, wighrystum scan,

seah on sinc, on sylfor, on searogymmas,

on ead, onæht, on eorcanstan,

on pas beorhtan burg bradan rices. (lines 32b-41a)

(Where once many a man glad-minded and gold-bright, clothed in splendor, proud and joyful with wine, shone in war-gear, and gazed on treasure, on silver, on worked gems, on wealth, on property, on precious stones, on the bright city of the broad kingdom.)

In their anthropocentric pride, the city's inhabitants may have wrongly imagined their earthly kingdom broad in both space and time, as everlasting. They were not wrong, however, about its ideal beauty-or perhaps, as we look on that beauty, its prediction of a present/future beauty. Less an authentic or accurate depiction of a Roman stronghold than of an idealized early medieval warrior hall, this (re)created world of the poem blurs the boundaries between nostalgia, either for the historical past or for one that should have been, and a desire for present/future world(s) that might be built from those stonesa present/future that will, however, inevitably be broken and left for others to wonder at and re-use. Significantly, the poem foregrounds this scene as the object of a shared gaze: the past observer of this ideal beauty elides with the present poet observing the observer, who is, in turn, observed by present/future readers gazing on the ruins of as well as in the poem.

As the present poem disintegrates in a second and final passage of manuscript damage in lines 42-48, that gaze- -those recurrent gazes-fall(s) finally upon the baths, a place of welcome warmth amidst winter frigidity. Bright with treasure and jewels, filled with song and companionship, this noble, wondrous world becomes more fully alive with the rush of hot water over cold stone. In the past, pæt wæs hydelice (line 41b), "that was convenient, useful"; in the poem's present, pæt is cynlic ping (line 47b), "that is a noble thing"-or perhaps a "kin-like" shared thing. The pun echoes the "hundred generations" earlier in the poem. It also, perhaps, implies a hope that some sort of reproductive futurity — biological, ideological, or textual-will ensure further continuity. Additionally, in the imagining of those envisioned baths, words, such as bosme and hrepre, invoke — and reanimate-living human bodies (Johnson 1980). The poem ends, that is, with (at least metaphorically) embodied desires in the present-or presents, plural—of speaker and reader.

Or, at least it does if one ignores the gaps of the ruined lines, in which that embodiment vanishes even as it appears. Between past hyðlic-ness and present cynlic-ness, wyrd silences the poem's bodies and embodied places. Line $42 \mathrm{~b}$ is erased, although line 43 still allows 
us to see and feel the harne stan and hate streamas of the baths. Hate recurs in line $45 \mathrm{~b}$, and line 45a's hringmere and line 46b's reference to pær pa bapu wæron in the past are intelligible. In the poem's final three lines, however, fragmentary echoes dissolve into the textual wound's silence. That is, perhaps, the essence of the poem's wyrd poetics, a poetics and an aesthetic rooted in the precarity of the always already lost. Encountering The Ruin, we can look with horror upon a deep past, and/or take pleasure in the fragile, always already perishing possibilities of present/future beauty. Our desire to build is intrinsically a desire for both creation and destruction, both survival and apocalypse. Similar to the imagined original builders and rebuilders of the ruined city, and similar to the early medieval poet who imagined them, in collaboration with wyrd, we readers become wyrhtan who craft a wrætlic imagined past from shattered and timeworn fragments of walls and of poems, such as The Ruin, and similar to the other wyrd-ruined poems in the manuscript. We can, therefore, also consider the way the wound connects those damaged texts sensually, through their common material precarity, as well as intellectually, through shared themes and genres.

In his 2017 collection, The Unstill Ones, Miller Oberman both translates and responds to The Ruin (Oberman 2017). The poet also offers translations of Riddles lines 63, 78, 82 and 94 from the Exeter Book, all texts from the damaged portion of the manuscript and consequently almost unsolvable-unreadable-because of their gaps and silences. In these collaborations with wyrd, Oberman juxtaposes the jewel (wrætt)-like images present in the extant fragments with the absences, the silences inherent in the manuscript damage. Attending to both the words and the gaps in these texts, he crafts a type of erasure poetry: his (re)creative acts of appropriation, destruction, and re-inscription constitute collaborations with change and loss, with wyrd materially manifest in the tenth-century manuscript read in the twenty-first.

Unlike Oberman, neither the poet who composed The Ruin nor the scribe who incorporated it into the Exeter Book could know how wyrd would affect the text. Neither could know that a burning brand would "ruin" the text and thereby allow-even require-us to collaborate with wyrd in our reading of the extant text. Yet, both may well have been keenly aware of the precarity of manuscripts, languages, and cultures. Therefore, for example, we might gather from other early medieval English texts, such as the Alfredian translation of Gregory's Pastoral Care and its lament of knowledge loss. Poet and scribe would have known the ways in which flaws in the original animal skin could create blemishes and holes in the manuscript's surface. They may have shared the anxiety about possible consequent subsequent damage most famously expressed (even ironically anticipated and celebrated as a wrætlic wyrd) elsewhere in the Exeter Book itself, in the book-moth riddle. Both poet and scribe were likely aware that language change that could make a collection of Old English poetry obsolete, and aware, too, that old, surplus manuscripts could be scraped and palimpsested, or even dismembered for use in binding later volumes. They could not know, but would hardly be surprised, that the Exeter Book would survive, not because of but despite its contents, because it could be used to store gold leaf in a later scriptorium. They could not know the fate of the text, any more than the builders and rebuilders could know that of the wall-stone, but The Ruin suggests that they could and should acknowledge its precarity, accept the horror and desire that such precarity provokes, and ultimately collaborate with it. Additionally, that acceptance of the text's precarity and untimeliness unsettles temporal subjectivity and allows-in some possible circumstances perhaps even compels-readers to collaborate with wyrd.

Reading The Ruin in this way raises a number of questions about the nature of our encounters with other texts and other humans, and the inhuman pasts and futures. It queries, for example, the extent to which our "archaeological" desires-for coherent scholarly interpretations "true" to the circumstances and contexts of original composition, for the objective discovery of sources and analogues-play with as well as against less "academic", but perhaps more existential, desires for sometimes queer touches (to use Carolyn Dinshaw's phrase) of empathy across time (Dinshaw 2012). Similar to Dinshaw, Elizabeth 
Freeman suggests we focus not on History (with a capital letter) as something "seamless, unified and forward moving" inexorably toward completion—or at least the fatalistically inevitable-but on a succession of moments marked by "forms of interruption" and "points of resistance" (Freeman 2010; Love 2007). For Freeman, as for Dinshaw, such points of resistance, among which we might include texts, such as The Ruin-and the encounters of both its early medieval poet with a (Roman) past and its post-medieval readers with a medieval literary past-are based on the desire for and engagement with temporal otherness, with wyrd. Unsettling our reading of the text as "safely" in the past can encourage us, too, to confront the horror of wyrd in new ways as it continues to become manifest in our own environment, our own unfolding of temporal change. In the end, however much we pretend to read objectively, we cannot but engage with texts of the past from our own "now" and with our own anxieties and preoccupations. Doing so consciously can help us not only to appreciate the Old English poetics of wyrd, but also to formulate our own strategies for engaging with the precarity of the anthropocene.

Funding: This research received no external funding.

Conflicts of Interest: The author declares no conflict of interest.

\section{Notes}

1 As Chris Abram (for example) observes, it has become "almost traditional" in the history of the poem's critical reception "to describe it as a ruin itself" (Abram 2000, p. 23). For the poem's translation heritage, especially in the twentieth and twenty-first centuries, see especially (Davies 2018, pp. 38-54).

2 See Thornbury (2006). The poem is, for example, commonly categorized as an elegy, a genre term itself paracritically applied to a group of poems, including the Wanderer and the Seafarer, in the absence of any historically documented early medieval use.

3 The poem's woldagas (25b) may refer directly or indirectly to something like the Yellow or Justinian Plague, the ravages of which on early medieval British monasteries—and the resultant trauma—is chronicled by Bede. On the course and nature of that epidemic, see (Maddicott 1997).

4 See (Thacker 2011, p. 1; Tabas 2015). While the term cosmic horror is most often associated with H. P. Lovecraft, as defined theoretically in his Supernatural Horror in Literature and deployed in his problematic fiction, in which dread produces a consequent abjection infamously voiced in the violent rhetoric of misogyny and racism, that abjection is reworked and reformulated by many twenty-first century examples of the "new weird" including, perhaps most relevantly, the ecological cosmic horror of Jeff Vandermeer and the queer desires of Caitlin Kiernan, as well as the widely influential work of writer and critic China Miéville.

5 The term "intra-action" is taken from (Barad 2007).

6 As Eileen Joy (2005) notes, the Ruin draws no specific moral from its observations; whatever wisdom may arise from contemplation of the poem's ruins is not defined in this text as it is in the Wanderer and other elegies with a speaking subject to anchor them.

7 On the late antique little ice age and its influence on Northern European, particularly Scandinavian, culture and mythopoetics, see (Gräslund and Price 2012, 2015). On the persistence of memory and trauma into the ninth century see (Holmberg et al. 2018). An increase in apocalyptic fear during that later period may be connected to the portents of unusually violent storms and intense auroral activity-reported in the Anglo-Saxon Chronicle-in the wake of solar flare eruptions and resulting geomagnetic storms: Sukhodolov et al. (2017). Roberta Frank argues the influence of skaldic imagery, especially that of storms and wintery weather, in Old English poems (Frank 2002). For a nuanced ecocritical reading of climate trauma and mythopoetics see (Abram 2018).

8 See (Davies 2018, pp. 20-29), on untimeliness of the poem's multiple apocalypses.

9 On the ruin as Roman: Wentersdorf (1977). The site is often identified more specifically as Bath, although Dunleavy (1959) favors Chester, and Herben (1939) suggests Hadrian's Wall. Against a specific location: Keenan (1966) and Lee (1973). Fell (1991) focuses on the theme of transitory nature of the world and worldly glory (Talentino 1978; Franks 1973). Thornbury (2000) argues for evocation of Roman rather than the commonly referenced Neolithic or bronze age barrow.

10 For Abram the poem echoes particularly the Encomium Urbis theme in late Latin poetry (Abram 2000, p. 24). Zanna (1991) defines the subgenre as "meditative reflection on fated downfall of great cities, their present and future state" (p. 524). Additionally, Schlauch (1941) on the Old English "Durham" and Alcuin's poem on York.

11 The terms recur throughout Land's work as collected in (Land 2011).

\section{References}

Abram, Christopher. 2000. In Search of Lost Time: Aldhelm and the Ruin. Quaestio 1: 23-44.

Abram, Christopher. 2018. Evergreen Ash: Ecology and Catastrophe in Old Norse Legend and Myth. Charlottesville and London: University of Virginia Press. 
Barad, Karen. 2007. Meeting the Universe Halfway: Quantum Physics and the Entanglement of Matter and Meaning. Durham: Duke University Press.

Bately, Janet. 1984. Time and the Passing of Time in the Wanderer and Related OE Texts. Essays and Studies 37: 1-15.

Critten, Rory. 2019. Via Rome: Medieval Medievalisms in the Old English Ruin. Journal of Medieval and Early Modern Studies 49: 209-21. [CrossRef]

Davies, Joshua. 2018. Visions and Ruins: Cultural Memory and the Untimely Middle Ages. Manchester: Manchester University Press.

Dinshaw, Carolyn. 2012. How Soon Is Now? Amateur Readers and the Queerness of Time. Durham: Duke University Press.

Dunleavy, Gareth. 1959. A ‘De Exidio' Tradition in the Old English Ruin? Philological Quarterly 38: 112-18.

Eaton, Tim. 2000. Plundering the Past: Roman Stonework in Medieval Britain. Stroud: Tempus.

Fell, Christine E. 1991. Perceptions of Transience. In Cambridge Companion to Old English Literature. Edited by Malcolm Godden and Michael Lapidge. Cambridge: Cambridge University Press, pp. 172-89.

Ferhatovic, Denis. 2019. Borrowed Objects and the Art of Poetry: Spolia in Old English Verse. Manchester: Manchester University Press.

Frank, Roberta. 2002. North Sea Soundings in Andreas. In Early Medieval English Texts and Interpretations. Edited by Elaine Treharne and Susan Rosser. Tempe: ACMRS, pp. 1-11.

Franks, Peter J. 1973. The Thematic Significance of entageweorc and Related Imagery in the Wanderer. Anglo-Saxon England 2: 253-69. [CrossRef]

Freeman, Elizabeth. 2010. Time Binds: Queer Temporalities, Queer Histories. Durham: Duke University Press, p. xxii.

Gräslund, Bo, and Neil Price. 2012. Twilight of the Gods? The Dust Veil Event of AD 536 in Critical Perspective. Antiquity 86: 428-43. [CrossRef]

Gräslund, Bo, and Neil Price. 2015. Excavating the Fimbulwinter? Archaeology, Geomythology and the Climate Event of AD 536. In Past Vulnerability: Volcanic Eruptions and Human Vulnerability in Traditional Societies Past and Present. Aarhus: Aarhus University Press, pp. 109-32.

Herben, Stephen J. 1939. The Ruin. Modern Language Notes 54: 37-39. [CrossRef]

Holmberg, Per, Bo Gräslund, Olaf Sundqvist, and Henrik Williams. 2018. The Rök Runestone and the End of the World. Futhark: International Journal of Runic Studies 9: 7-38. [CrossRef]

Howe, Nicholas. 1989. Migration and Mythmaking in Anglo-Saxon England. New Haven: Yale University Press.

Johnson, William. 1980. The Ruin as Body-City Riddle. Philological Quarterly 59: 397-411.

Joy, Eileen. 2005. On the Hither side of Time: Tony Kushner's Homebody/Kabul and the Old English Ruin. Medieval Perspectives. p. 19. Available online: http://hcommons.org/deposits/objects/hc:24772/datastreams/CONTENT/content (accessed on 23 February 2022).

Keenan, Hugh T. 1966. The Ruin as Babylon. Tennessee Studies in Literature 11: 109-17.

Land, Nick. 2011. Fanged Noumena. Collected Writings 1987-2007. Edited by Robin Mackay and Ray Brassin. Falmouth: Urbanomic.

Lee, Anne Thompson. 1973. The Ruin: Bath or Babylon? A Non-Archaeological Investigation. Neuphilologische Mitteilungen 74: 443-55. Love, Heather. 2007. Feeling Backward: Loss and the Politics of Queer History. Cambridge: Harvard University Press.

Maddicott, John R. 1997. Plague in Seventh-Century England. Past and Present 156: 7-54. [CrossRef]

Niles, John. 2006. Old English Enigmatic Poems and the Play of Texts. Turnhout: Brepols, p. 4.

Noys, Benjamin. 2008. Horror Temporis. In Collapse IV. Falmouth: Urbanomic, Available online: http:/ / www.urbanomic.com (accessed on 10 December 2021).

Oberman, Miller. 2017. The Unstill Ones. Princeton: Princeton University Press.

Pritchard, Sara. 2019. Epilogue. Field Notes from the End of the World: Light, Darkness, Energy, and Endscape in Polar Night. Journal of Energy History/Revue d'Histoire de l'Energie. p. 2. Available online: http:/ / energyhistory.eu/node/140 (accessed on 23 February 2022). Ramey, Peter. 2017. The Riddle of Beauty: The Aesthetics of Wrætlic in Old English Verse. Philological Quarterly 114: 457-81. [CrossRef] Royle, Nicholas. 2011. Veering: A Theory of Literature. Edinburgh: Edinburgh University Press.

Schlauch, Margaret. 1941. An Old English 'Encomium Urbis'. JEGP 40: 14-28.

Sukhodolov, Timofei, Ilya Usoskin, Eugene Rozanov, Eleanna Asvestari, William T. Ball, Mark A. J. Curran, Hubertus Fischer, Gennady Kovaltsov, Fusa Miyake, Thomas Peter, and et al. 2017. Atmospheric impact of the strongest known solar particle storm of 775 AD. Scientific Reports 7: 45257. Available online: https://www.nature.com/articles/srep45257 (accessed on 23 February 2022).

Tabas, Brad. 2015. Dark Places. Miranda. p. 11. Available online: http:/ / miranda.revues.org/7012 (accessed on 23 February 2022 ).

Talentino, Arnold V. 1978. Moral Irony in the Ruin. Papers in Language and Literature 14: 3-10.

Thacker, Eugen. 2011. In the Dust of this Planet. Winchester: Zero Books.

Thornbury, Emily V. 2000. Eald enta geweorc and the Relics of Empire: Revisiting the Dragon's Lair in Beowulf. Quaestio 1: 82-92.

Thornbury, Emily V. 2006. Admiring the Ruined Text: The Picturesque in Editions of Old English Verse. In New Medieval Literatures. Edited by Rita Copeland, David Lawton and Wendy Scase. Turnhout: Brepols, vol. 8, pp. 215-44.

Trilling, Renee. 2009. The Aesthetics of Nostalgia: Historical Representation in Old English Verse. Toronto: University of Toronto Press.

Wentersdorf, Karl P. 1977. Observations on the Ruin. Medium Ævum 46: 171-80. [CrossRef]

Zanna, Paolo. 1991. Descriptiones urbium and Elegy in Latin and Vernaculars in the Early Middle Ages. At the Crossroads between Civic Engagement, Artistic Enthusiasm and Religious Meditation. Studia Mediaevalia 32: 523-96. 